\author{
한우 c-fos 유전자의 염기서열 및 발현분석 \\ 유성란* · 정행진* · 정기철* · 이준헌* · 조규완** · 최재관*** . 나기준*** · 상병찬* \\ 충남대학교 동물자원학부*, 수의학과**, 농촌진흥청 축산기술연구소***
}

\title{
Sequence and Expression Analysis of c-fos Proto-oncogene in Korean Cattle (HANWOO)
}

\author{
S. L. Yu*, H. J. Chung*, K. C. Jung*, J. H. Lee*, K. W. Cho**, J. G. Choi***, \\ K. J. Na*** and B. C. Sang* \\ Division of Animal Science and Resources,* \\ Department of Veterinary Medicine**, Chungnam National University, Daejeon 305-704, Korea
}

Daekwanryong Branch, National Livestock Research Institute, R.D.A., Phyongchang 232-952, Korea***

\begin{abstract}
Cellular FOS(c-fos) protein is a transcription factor that forms heterodimers mostly with c-jun family and stimulates the transcription of genes containing AP-1 regulatory elements. This c-fos expression can control growth and differentiation of various precursor cells including myoblasts. The controls by c-fos gene have been identified for affecting skeletal muscle fiber traits which are the key determinants of meat quality in pigs. As a first step for identifying the relationship between c-fos gene and meat quality traits in cattle, we fully sequenced 1,443 bp of Hanwoo c-fos mRNA and analyzed expression patterns from various organs and muscle tissues. The sequence identities of Hanwoo c-fos with that of human, pig and mouse showed 89.8\%, 93.3\% and $87 \%$, respectively. Analyses of the northern blot showed high c-fos expressions were obtained in spleen and rib muscle from 7 organs and 9 different parts of muscles investigated. These results presented here can be used as a valuable marker for meat quality related traits in cattle with further verification.
\end{abstract}

(Key words : Bovine, c-fos, Sequence homology, Expression pattern, Meat quality)

\section{I 서 론}

Cellular Fos(c-fos) 유전자는 생쥐에 전이되어 골수 암을 유발시키는 FBJ murine osteosarcoma virus의 연구에 의해 처음 밝혀졌으며(Finkel 등, 1966), 일반적으로 c-jun family와 결합하여 전 사조절인자(transcription factor)로써 역할을 하는 핵내 인단백질중 하나이다. 특히 이 유전자는 주로 activating factor-1(AP-1) regulatory element 를 가진 유전자들의 발현을 조절하는 것으로 알려져 있다(Glover 등, 1995). 또한, c-fos 유전
자는 수정란의 성장과 분화, 혈구 형성, 신경 계, 근육, 골모세포의 통제에 중요한 역할을 한 다는 것이 in vitro 실험에 의해 밝혀졌으며, in vivo 실험결과에서는 c-fos 유전자를 과발현시킬 경우 생쥐에서 뼈, 연골, 혈구형성 세포발달에 영향을 주었다고 보고한 바 있다(Wang 등, 1991). c-fos 유전자를 knockout시킨 생쥐에서는 성장이 둔화되고, 뼈의 재생산 및 치아의 맹출 이 결핍되며 혈구생성에 변화가 일어났고 (Wang 등, 1992; Johnson 등, 1992), 돌연변이 (mutant) 생쥐에서는 파골 세포와 대식세포의

\footnotetext{
Corresponding author : B. C. Sang, Division of Animal Science and Resources, College of Agriculture and Life Sciences, Chungnam National University, Daejeon 305-704, Korea. Tel : 042-821-5788, Fax : 042-823-2766, E-mail : bcsang@cnu.ac.kr
} 
관계가 변화하였고(Grigoriadis 등, 1995), 신경 계의 흥분성과 생존을 조절하는 세포의 메커니 즘을 조절하는 등의 다양한 역할에 c-fos 유전 자가 관여하는 것으로 보고되어 있다(Zhang 등, 2002).

이 c-fos 유전자는 myogenesis와도 관계가 있 는 것으로 알려져 있는데 특히, 근육세포가 근 육으로 발달하는 과정에서 근육세포의 terminal differentiation에 중요한 요인으로 작용하는 myogenin과 myoD 유전자가 c-fos promoter의 E-box에 결합하여 c-fos 유전자의 발현을 억제 시킨다는 보고가 있다(Trouche 등, 1995). 또한 c-fos 유전자의 down regulation이 transcription factor AP-1을 조절하여 myocyte의 terminal differentiation과 myotube의 형성에 필수적인 역 할을 한다고 알려졌다(Lehtinen 등, 1996). 최근 돼지에서 c-fos 유전자의 염기서열상의 변이가 백색섬유의 양을 증가시켰으나 백색섬유의 직 경이 감소하였다는 결과로 c-fos 유전자는 육질 의 향상에 영향을 미치는 것으로 추측되어졌다 (Reiner 등, 2002).

이와 같이 c-fos 유전자는 골격 근육(skeletal muscle)의 발달에 있어서 차이를 나타내는 것으 로 알 수 있는데, 현재까지 소에서 c-fos 유전 자의 연구는 전무한 실정이며 한국 재래종인 한우를 이용해 소에서 c-fos 유전자의 발현양상 과 mRNA 염기서열을 알아보기 위하여 본 연 구를 수행하였다.

\section{재료 및 방법}

\section{1. 공시재료}

본 연구에 사용된 공시재료는 축산기술연구 소에서 도축된 12 개월령 한우 1 두의 9 개 근육 부위(안심, 갈비, 등심, 목심, 채끝, 우둔, 설도, 사태, 양지) 및 7 개의 장기 조직(좌심방, 우심 방, 간, 비장, 신장, 우심실, 좌심실)을 이용하였 다. RT-PCR 및 Northern blotting을 위한 신선한 시료를 얻기위해 도축한 후 30 분 이내에 모든 조직이 채취되었으며, 채취된 조직은 바로 액 체질소에 넣어 실험실로 옮겨졌다.

\section{Total RNA 추출}

한우의 각 조직 $1.5 \mathrm{~g}$ 를 $15 \mathrm{~m} \ell$ 의 Tri Reagent (Molecular Research Center, INC.) 용액으로 분쇄 한 다음 chloroform $7.5 \mathrm{~m} \ell$ 을 첨가하여 혼합한 후 $4^{\circ} \mathrm{C}$ 서 $12,000 \mathrm{rpm}$ 으로 원심분리하여 RNA 층을 얻었다. RNA층을 새로운 튜브에 옮긴 후, 0.7 volume의 isopropanol로 $\mathrm{RNA}$ 를 완전히 침전 시킨 다음 $75 \%$ ethanol-DEPC(diethylpyrocarbonate) 로 씻어 낸 후 DEPC 처리된 RNase-free $\mathrm{H}_{2} \mathrm{O}$ 에 RNA를 용해시켰다. 추출된 RNA의 농도는 Spectrophotometer(Ultrospec2000, Pharmacia, U.S.A.) 를 이용하여 $260 \mathrm{~nm}$ 파장에서 측정한 후, -70 ${ }^{\circ} \mathrm{C}$ 저장하여 실험에 사용하였다.

\section{3. 한우의 c-fos 유전자 증폭을 위한 database search}

소에서 밝혀진 c-fos 유전자의 염기서열의 존 재 유무를 알아보기 위하여 먼저 GenBank 및 TIGR database를 돼지의 c-fos mRNA coding sequence(GenBank accession number:AJ132510)를 이용하여 BLAST search를 실시하였다. BLAST search 결과 GenBank에는 소의 c-fos 유전자 중 일부분인 $381 \mathrm{bp}$ 만이 밝혀졌음을 확인할 수 있 었으며(GenBank accession number:AF069515), TIGR에는 assembled된 EST가 존재함을 확인하 였다. 돼지 mRNA와 소의 TIGR EST sequence 를 alignment해 본 결과 두 염기서열 간의 homology가 매우 높아 $\left(6.7 \times \mathrm{e}^{-116}\right)$ 이 TIGR EST sequence (TC126632)는 소의 c-fos 유전자 임이 확인이 되었으며(Fig. 1), 또한 돼지의 c-fos 유전자 구성과 비교하여 볼 때 이 염기서 열은 소의 c-fos 유전자 exon 1부터 exon 4의 일부분까지 확인이 되었다. 최근에 보완된 TIGR database에는 이 염기서열에 6개의 EST가 첨가되어 exon 1 부터 exon 4 의 전 부분의 염기 서열이 새롭게 보고되어 있었다(TC153785). 이 결과로 미루어 볼 때 최근에 많은 연구가 된 EST들은 새로운 유전자의 염기서열을 얻는데 중요한 수단이 될 수 있으며 이 방법은 소에서 알려지지 않은 유전자를 PCR 증폭하기 위하여 
Pig : 2639 GAGACAGACCAGCTAGAAGACGAGAAGTCTGCTTTGCAGACTGAGATCGCCAACCTGCTG 2698 (AJ132510)

BOVINE : 652 GAGACAGACCAACTAGAAGATGAGAAGTCGGCTTTGCAGACAGAGATTGCCAATCTGCTG 711 (TC126632)

Pig : 2699 AAGGAGAAGGAAAAACTCGAGTTCATCCTGGCAGCTCACCGACCTGCCTGCAAGATCCCT 2758

BOVINE : 712 AAGGAGAAGGAAAAACTCGAGTTCATCCTAGCGGCTCACCGACCTGCCTGCAAGATCCCC 771

Pig : 2759 GATGACCTGGGCTTCCCTGAAGAGATGTCTGTGGCTTCCCTTGATCTGAGTGGGGGCCTG 2818

BOVINE : 772 GATGACCTGGGCTTCCCAGAAGAGATGTCTGTGGCTTCTCTTGATCTGAGTGGGGGCCTG 831

Pig : 2819 CCTGAGGCTGCCACCCCCGAATCTGAGGAGGCCTTCACCCTGCCCCTCCTCAATGACCCG 2878

BOVINE : 832 CCTGAGGCTGCCACCCCTGAATCTGAGGAGGCCTTCACCCTGCCACTCCTCAATGACCCT 891

Pig : 2879 GAGCCCAAGCCCTCCGTGGAGCCAGTCAAGAACGTCAGCAGCATGGAGCTGAAGGCCGAG 2938

BOVINE : 892 GAGCCCAAGCCCTCAGTGGAGCCCGTCAAGAGCGTCGGCAGCATGGAGCTGAAGGCTGAG 951

Pig : 2939 CCCTTTGATGACTTCCTGTTCCCAGCATCGTCCAGGCCCGGCGGCTCTGAGACAGCCCGC 2998

BOVINE : 952 CCCTTTGATGACTACATGTTCCCAGCATCATCCAGGCCCAGCGGCTCGGAGACCGCCCGC 1011

Pig : 2999 TCTGTGCCGGACATGGACCTGTCTGGTTCCTTCTATGCAGCAGACTGGGAGCCCCTGCAT 3058

BOVINE : 1012 TCTGTGCCAGACATGGACCTGTCTGGTTCCTTCTATGCAGCAGACTGGGAGCCCCTGCAT 1071

Pig : 3059 GGTGGCTCCCTGGGGATGGGGCCCATGGCCACAGAGCTGGAGCCCCTGTGTACCCCGGTG 3118

BOVINE : 1072 GGTGGCTCCCTGGGGATGGGGCCTATGGCCACGGAGCTGGAGCCCCTGTGCACCCCGGTG 1131

Pig : 3119 GTCACCTGCACCCCCAGCTGCACTACTTACACGTCTTCCTTCGTCTTTACCTACCCCGAG 3178

BOVINE : 1132 GTCACCTGTACTCCCAGCTGCACTACTTACACGTCTTCCTTCGTCTTCACCTACCCTGAG 1191

Pig : 3179 GCTGACTCCTTCCCCAGCTGTGCGGCTGCCCACCGCAAGGGCAGCAGC 3226

BOVINE : 1192 GCTGACTCCTTCCCCAGCTGTGCGGCTGCCCACCGCAAGGGCAGCAGC 1239

Fig. 1. Sequence search result of pig c-fos exon 4 sequence (GenBank accession number AJ132510) against TIGR BtGI (Bos taurus Gene Index) for easily extract cattle c-fos sequence which was not investigated before. High sequence homology (94.4\%) between the two sequences indicates that the bovine $c$-fos sequence is genuine.

인간과 쥐 등 알려진 염기서열을 alignment하여 reverse transcriptase(Promega, U.S.A.), 0.5 Unit primer를 제작해 온 기존의 방법과 더불어 원하 recombinant RNasin ribonuclease inhibitor(Pro는 유전자를 쉽게 찾아낼 수 있는 방법이라고 mega, U.S.A.) 조성으로 $42^{\circ} \mathrm{C}$ 서 1 시간 반응한 생각한다.

\section{RT-PCR 및 Cloning}

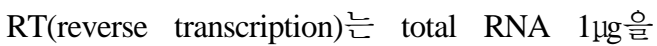
결과 생성된 1st cDNA를 이용하여 PTC-200(MJ Research, U.S.A.)에서 PCR를 실시하여 c-fos 유 전자를 증폭하였다. PCR 혼합액에는 $1 \mathrm{st} \mathrm{cDNA}$, $0.2 \mathrm{mM}$ dNTPs, forward와 reverse의 $2 \mathrm{pmol}$ primer, 0.1 Unit Taq polymerase(Bioneer, KOREA), 이용하여 실시하였다. RNA $1 \mu \mathrm{g}$ 에 $1 \times$ enzyme $1 \times$ buffer 조성으로 증폭시켰다. 사용한 primer buffer, $50 \mathrm{ng}$ oligo dT, $0.25 \mathrm{mM}$ dNTPs, 1 Unit 는 Table 1에서 보는 것과 같이 TIGR(The Insti- 
Table 1. Primers used for amplifying bovine c-fos gene in this study

\begin{tabular}{lllc}
\hline Primer name & \multicolumn{1}{c}{ Primer sequence $\left(5^{\prime}-3^{\prime}\right.$} & \multicolumn{1}{c}{ Locations ${ }^{1)}$} & Anneal. temp. $\left({ }^{\circ} \mathrm{C}\right.$ \\
\hline \hline c-Fos \#1 & CTTAAGGAGCTGACACAGAG & 11-30(TC126632) & 58 \\
c-Fos \#2 & ATCTTGCAGGCAGGTCGGTG & 748-767(TC126632) & \\
c-Fos \#3 & GATTGCCAATCTGCTGAAGG & 696-715(TC126632) & 58 \\
c-Fos \#4 & TTCAAGTCCTTGAGGCCCAC & 3423-3442(AJ132510) & \\
\hline
\end{tabular}

\footnotetext{
${ }^{1)}$ Locations are based on the TIGR assembled bovine EST sequence for TC126632 and the porcine c-fos GenBank sequence for AJ132510.
}

tute for Gene Research, http://www.tigr.org/)의 소 의 EST(Expressed Sequence Tag)와 NCBI(National Center for Biotechnology Information, http://www.ncbi.nlm.nih.gov/)에 보고되어 있는 돼지의 c-fos 유전자에서 primer를 제작하여 $\mathrm{PCR}$ 에 이용하였다. 각 primer의 염기서열 및 정보는 Table 1 에 제시되어 있다. 1, 2번의 primer는 c-fos 유전자의 5'쪽을, 3, 4번의 primers는 c-fos 유전자의 3'쪽을 증폭하는데 이 용이 되었다. $\mathrm{PCR}$ 의 반응조건은 $94^{\circ} \mathrm{C}$ 서 5 분 으로 1 회 실시한 후, $94^{\circ} \mathrm{C}$ 서 30 초, $58^{\circ} \mathrm{C}$ 서 30 초, $72^{\circ} \mathrm{C}$ 서 30 초씩 총 35 회를 증폭시키고, 마지막으로 $72^{\circ} \mathrm{C}$ 서 10 분간 더 반응시켰다. $\mathrm{PCR}$ 이 끝난 후 $5 \mu \ell$ 의 증폭산물을 $1.2 \%$ 의 agarose gel에 전기영동하여 증폭여부 및 크기 를 확인하였다. 이 증폭산물들은 pGEM-T easy vector(Promega, U.S.A.)에 ligation시켜 cloning한 후 제한효소인 EcoRI의 처리로 insert의 유무 및 정확한 insert size를 확인하였다.

\section{5. c-fos 유전자의 염기서열 결정 및 분석}

각 clone들의 염기서열을 결정하기 위하여 재 조합된 Plasmid DNA $200 \mathrm{ng}$ 을 Bigdye terminator(PE Applied Biosystems, U.S.A.)를 사용 하여 cycle sequencing reaction을 실시하였다. PCR 반응은 PE 9600(PE Applied Biosystems, U.S.A.)을 이용하여 $96^{\circ} \mathrm{C}$ 서 1 초, $50^{\circ} \mathrm{C}$ 서 5 초, $60^{\circ} \mathrm{C}$ 서 4 분간의 조건으로 25 회 실시하였 고, 반응이 끝난 $\mathrm{PCR}$ 산물은 ethanol로 정제한 후, $\mathrm{ABI} 377$ 자동염기서열 분석장치(PE Applied Biosystems, U.S.A.)를 사용하여 염기서열을 결 정하고 분석하였다. 결정된 염기서열을 $\mathrm{NCBI}$ (National Center for Biotechnology Information, http://www.ncbi.nlm.nih.gov/gorf/gorf.html)의 open reading frame finder에서 아미노산으로 예측하고 이를 GeneDoc(http://www.psc.edu/blomed/genedoc/) 프로그램에서 종간의 아미노산 상동성을 조사 하였다.

\section{Northern blot analysis}

각 조직에서 추출한 total RNA 40ug을 $3.3 \mathrm{vol}-$ ume의 sample buffer(1.3×MOPS[3-(N-morpholino)propane sulfonic acid] running buffer, 8.1\% formaldhyde, $65 \%$ formamide)에 넣고 $65^{\circ} \mathrm{C}$ 서 5 분간 반응시켜 denaturation 후, 0.7 volume의 loading dye(50\% glycerol, $0.4 \%$ Bromophenol Blue, $0.1 \%$ Xylene Cyanol)와 섞어 formaldehydeagarose gel( $1 \%$ agarose, $1 \times$ MOPS, $6.2 \%$ formaldehyde)에서 80 volt로 3 시간동안 전기영동한 후 ethidium bromide로 염색하였다. 추출된 mRNA의 상태는 $18 \mathrm{~s}, 28 \mathrm{~s}$ ribosomal RNA의 순 도를 보고 결정을 하였다.

이 gel로부터 RNA를 $20 \times \mathrm{SSC}$ 를 이용하여 Nylon-membrane에 삼투압작용으로 20시간 transfer 한 다음 U.V. crosslinker(Upland, U.S.A.)로 RNA 를 membrane에 완전히 고정시켰다. Membrane은 $42^{\circ} \mathrm{C}$ 서 pre-hybridiztion solution $(5 \times \mathrm{SSC}, 5 \times$ Denhart's solution, $100 \mu \mathrm{g} / \mathrm{m} \ell$ Herring sperm DNA, $50 \%$ formamide)에 넣고 1 시간 동안 반응 시킨 후, Redi Prome II kit(Amersharm, U.S.A)를 이용해 실온에서 1 시간동안 $\left[a^{32} \mathrm{P}\right] \mathrm{dCTP}$ 방사성 동위원소로 labelling한 c-fos cDNA중 약 760 bp 를 probe로 이용하여 22시간 정도 hybridization 을 실시하였다. Hybridization한 것을 $2 \times \mathrm{SSC}$, $0.1 \% \mathrm{SDS}$ 용액으로 한번 세정한 후, 같은 용액 으로 $42^{\circ} \mathrm{C}$ 서 10 분간 세정 후에 $1 \times \mathrm{SSC}$, 
$0.1 \% \mathrm{SDS}$ 용액으로 $42^{\circ} \mathrm{C}$ 서 10 분간 세정한 다 음 원하는 정도의 signal이 나타내면 X-ray film 을 넣고 $-70^{\circ} \mathrm{C}$ 서 3 일간 감광시킨 후 현상하 였다.

\section{III 결과 및 고찰}

\section{1. 한우 C-fos 유전자의 PCR 및 cloning}

한우의 c-fos 유전자 coding sequence를 알아 내기 위하여 추출한 mRNA를 이용하여 Table 1 의 primer로 RT-PCR을 하였다. 원하고자 하는 증폭산물의 크기인 약 $760 \mathrm{bp}$ 의 5'쪽 c-fos 유전 자 증폭산물과 약 $760 \mathrm{bp}$ 의 3'쪽의 증폭산물이 얻어 이를 pGEM-T vector(Promega, U.S.A.)에 ligation시켜 Fig. 2에서 보는 것과 같이 c-fos 유

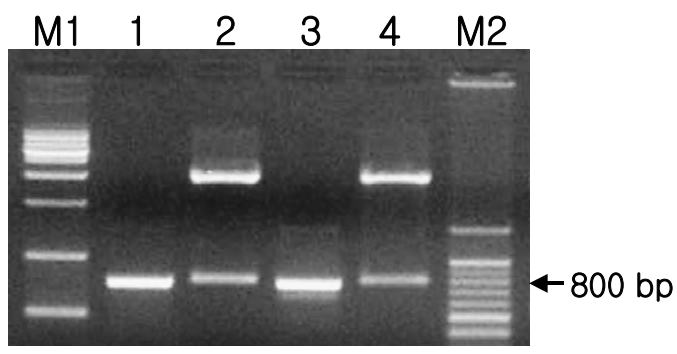

Fig. 2. A $1.2 \%$ agarose gel showing cloned bovine c-fos RT-PCR products. Lane 1: $5^{\prime}$ it of bovine c-fos gene, lane 2: A c-fos 5' me digested with EcoRI restriction enzyme, lane 3: $3^{\prime}$ rt of bovine c-fos gene, lane 4: A c-fos $3^{\prime}$ ine digested with EcoRI restriction enzyme, $\mathrm{M} 1$ and $\mathrm{M} 2$ : $1 \mathrm{~kb}$ and 100 bp size standards, respectively(ELPIS, KOREA).
전자의 5' $3^{\prime}$ 치가 삽입된 clone들을 얻을 수 있었다. 이 두 clone은 약 $70 \mathrm{bp}$ 정도가 겹 쳐지도록 만들었다.

2. c-fos 유전자의 mRNA 염기서열 및 아미 노산 서열의 비교분석

c-fos 유전자는 Van Straaten 등에 의해 사람 의 경우 mRNA가 $2.2 \mathrm{~kb}$ 의 길이를 가지고 4 개 의 exon으로 구성되어 있는 것으로 보고되었고 (GenBank accession number: V01512), 돼지의 경 우 Reiner 등(2000)에 의해 genomic DNA $4.2 \mathrm{~kb}$ 로 4개의 exon을 가지고 있음을 보고(GenBank accession number: AJ132510)한 바에 비해 소에 대한 c-fos 유전자의 염기서열은 mRNA의 381 $\mathrm{bp}$ 만이 보고되어 있는 상태이다(GenBank accession number: AF069515). 이 연구에서 처음 밝 혀진 소의 c-fos 유전자 전체 coding sequence를 다른 종에서 밝혀진 genomic organization과 비 교하여 살펴 본 결과 소도 다른 종과 마찬가지 로 4개의 exon으로 구성이 되어 있으며(Fig. 3), 종간에 높은 상동성을 보이는 것을 알 수 있었 다(Table 2). 특히 돼지와 소 간의 상동성이 93.5\%로 가장 높게 나타난 것으로 보아 돼지의

Table 2. Sequence homology for the c-fos mRNAs among species

\begin{tabular}{lccc} 
& & & (unit:\%) \\
\hline Species & Pig & Human & Mouse \\
\hline \hline Hanwoo & 93.5 & 89.8 & 87.0 \\
Pig & - & 91.8 & 89.3 \\
Human & 91.8 & - & 88.5 \\
\hline
\end{tabular}

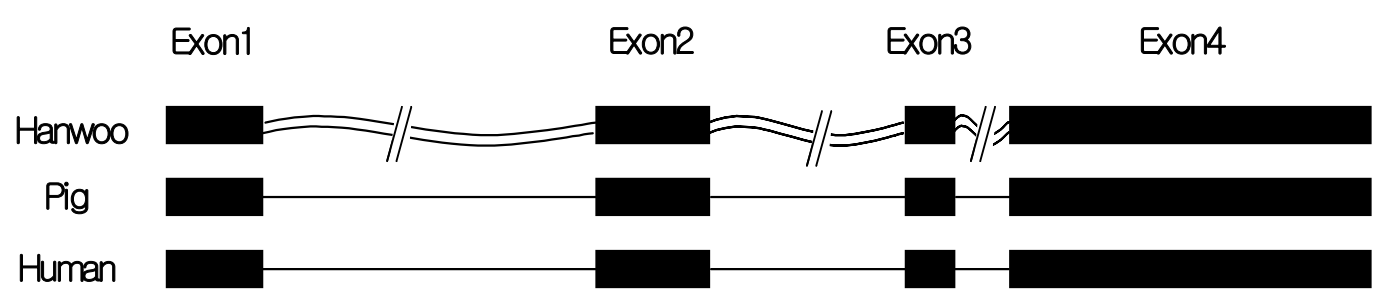

Fig. 3. Genomic organization of the c-fos gene among species. The intron sizes among species are also highly conserved. based on human and pig sequence information. 
염기서열을 이용하여 제작된 primer 4가 성공적 으로 PCR된 것은 두 종간의 높은 상동성에 기 인한 것으로 사료된다.

또한, 이 연구를 통하여 한우에서 밝혀진 염 기서열을 기존에 GenBank에 등록된 소의 염 기서열과 비교하여 본 결과 $278 \mathrm{bp}$ 중 총 5 개 의 염기가 틀린 것을 알 수 있었다(Fig. 4). 또 한 최근에 새롭게 assembled된 TIGR의 TC153785와 한우의 C-fos 유전자의 염기서열 을 비교하여 본 결과 5 개의 염기가 상이함이 밝혀졌다. 이 예상 돌연변이 염기들은 한우
특이적 $\mathrm{SNP}($ single nucleotide polymorphism) marker일 가능성이 매우 높으며, 돼지에서 c-fos 유전자의 돌연변이가 육질의 향상에 영 향을 준다는 보고가 있었으므로 이 $\mathrm{SNP}$ markers는 혈연관계가 없는 24마리의 한우개 체를 이용하여 추가 분석함으로서 이 연구에 서 밝혀진 $\mathrm{SNP}$ 들이 sequencing이나 PCR에 의 한 오류가 아니라 한우 고유의 marker임을 확 인함과 동시에 한우의 육질향상에 중요한 역 할을 할 것으로 사료된다.

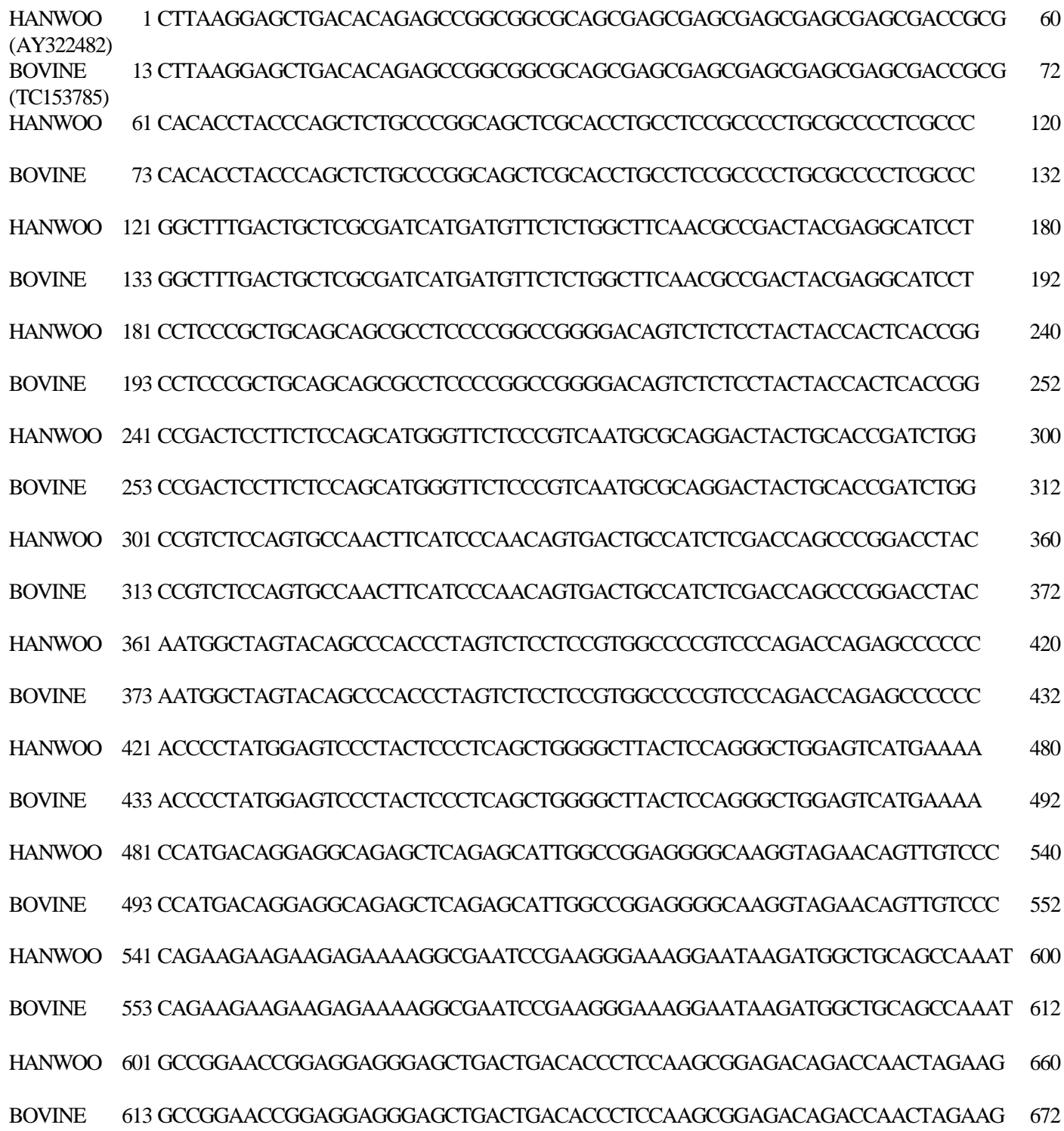


HANWOO 661 ATGAGAAGTCGGCTTTGCAGACAGAGATTGCCAATCTGCTGAAGGAGAAGGAAAAACTCG 720

BOVINE 673 ATGAGAAGTCGGCTTTGCAGACAGAGATTGCCAATCTGCTGAAGGAGAAGGAAAAACTCG 732

HANWOO 721 AGTTCATCCTAGCGGCTCACCGACCTGCCTGCAAGATCCCCGATGACCTGGGCTTCCCAG 780

BOVINE 733 AGTTCATCCTAGCGGCTCACCGACCTGCCTGCAAGATCCCCGATGACCTGGGCTTCCCAG 792

HANWOO 781 AAGAGATGTCTGTGGCTTCTCTTGATCTGAGTGGGGGCCTGCCTGAGGCTGCCACCCCTG 840

BOVINE 793 AAGAGATGTCTGTGGCTTCTCTTGATCTGAGTGGGGGCCTGCCTGAGGCTGCCACCCCTG 852

HANWOO 841 AATCTGAGGAGGCCTTCACCCTGCCACTCCTCAATGACCCTGAGCCCAAGCCCTCAGTGG 900

BOVINE 853 AATCTGAGGAGGCCTTCACCCTGCCACTCCTCAATGACCCTGAGCCCAAGCCCTCAGTGG 912

HANWOO 901 AGCCCGTCAAGAGCGTCGGCAGCATGGAGCTGAAGGCTGAGCCCTTTGATGACTACATGT 960

BOVINE 913 AGCCCGTCAAGAGCGTCGGCAGCATGGAGCTGAAGGCTGAGCCCTTTGATGACTACATGT 972

HANWOO 961 TCCCAGCATCATCCAGGCCCAGCGGCTCGGAGACCGCCCGCTCTGTGCCAGACATGGACC 1020

BOVINE 973 TCCCAGCATCATCCAGGCCCAGCGGCTCGGAGACCGCCCGCTCTGTGCCAGACATGGACC 1032

HANWOO 1021 TGTCTGGTTCCTTCTATGCAGCAGACTGGGAGCCCCTGCATGGTGGCTCCCTGGGGATGG 1080

BOVINE 1033 TGTCTGGTTCCTTCTATGCAGCAGACTGGGAGCCCCTGCATGGTGGCTCCCTGGGGATGG 1092

HANWOO 1081 GGCCTATGGCCACGGAGCTGGAGCCCCTGTGCACCCCGGTGGTCACCTGTACTCCCAGCT 1140

BOVINE 1093 GGCCTATGGCCACGGAGCTGGAGCCCCTGTGCACCCCGGTGGTCACCTGTACTCCCAGCT 1152

HANWOO 1141 GCACTACTTACACGTCTTCCTTCGTCTTCACCTACCCTGAGGCTGACTCCTTCCCCAGCT 1200

BOVINE 1153 GCACTACTTACACGTCTTCCTTCGTCTTCACCTACCCTGAGGCTGACTCCTTCCCCAGCT 1212

HANWOO 1201 GTGCGGCTGCCCACCGCAAGGGCAGCAGCAGCAACGAGCCTTCCTCTGACTCGCTCAGCT 1260

BOVINE 1213 GTGCGGCTGCCCACCGCAAGGGCAGCAGCAGCAACGAGCCTTCCTCTGACTCGCTCAGCT 1272

HANWOO 1261 CACCCACGCTGCTGGCCCTGTGAGCGGGCAGAGAGGGGAGGCAGTGGGCGTGCACGTGGC 1320

BOVINE 1273 CACCCACGCTGCTGGCCCTGTGAGCGGGCAGAGAGGGGATGCAGTGGGCGTGCACGTGGC 1332

HANWOO 1321 CACTGCCTGAGTTGGCGCATTACAGAGAGGAGAAACACGTCTTCCCTCGAGGGTTCCCAT 1380

BOVINE 1333 CACTGCCTGAGTTGGCGCATTACAGAGAGGAGAAACACGTCTTCCCTCGAGGGTTCCCAT 1392

HANWOO 1381 AGACCTAGGGAGGACCTTATCTGTGCGTGAAACACACCAGGCTGTGGGCCTCAAGGACTT 1440

BOVINE 1393 AGACCTAGGGAGGACCTTATCTGAGCGTGAAACACACCATGCTGAGGGCCTCAAGGACTT 1452

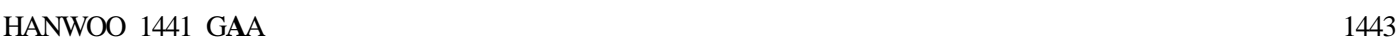

BOVINE 1453 GCA 1455

Fig. 4. Alignment of c-fos mRNA sequences of Hanwoo (generated in this study) and the bovine c-fos sequences downloaded from the TIGR (accession number 153785). The mismatch sequences are bold. 


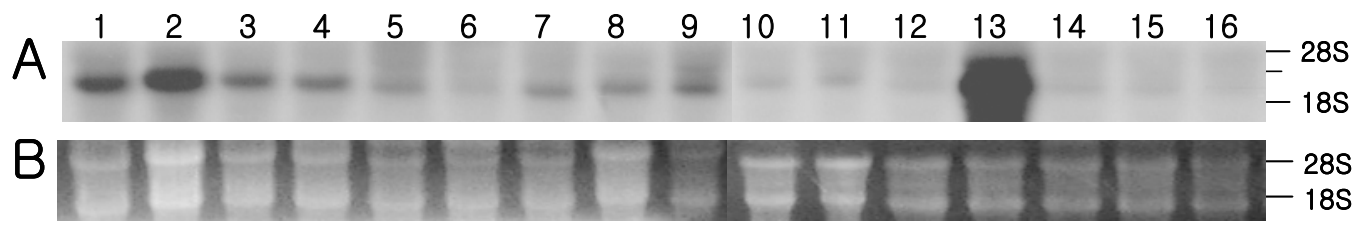

Fig. 6. Northern hybridization results of the c-fos gene in various muscles and organs. A: Results from 32P-labelled c-fos probe, B: Extracted total RNA on 1\% agarose gel. Lane 1: lean meat of short ribs, lane 2: the ribs, lane 3: sirloin, lanes 4-9: different parts of muscles, lane 10: left atrium, lane 11: right atrium, lane 12: liver, lane 13: spleen, lane 14: kidney, lane 15: right ventricle, and lane 16: left ventricle.

c-fos 유전자가 lymphocyte의 증식에 관련이 있 다는 보고(Zhang et al. 1999)가 있는 것으로 보 아 c-fos 유전자가 다른 조직에 비해 비장조직 에서 많은 발현량을 보이는 것으로 추측된다.

\section{Accession number}

한우 c-fos 유전자의 GenBank Accession number는 AY322482이다.

$$
\text { IV 요 약 }
$$

c-fos 유전자는 전사조절인자로서 주로 c-jun family와 결합하여 heterodimers를 형성하며 AP-1 조절 부위를 가지는 유전자들의 전사를 조절하는 것으로 알려져 있다. 이 유전자의 발 현은 myoblasts를 비롯한 여러 세포의 분화와 성장을 조절하며 최근 돼지에서 육질에 영향을 미치는 근섬유와 관련된다는 보고가 있다. 본 연구는 소에서 육질과 c-fos 유전자와의 관계를 알아보기 위한 기초자료로서 총 $1,443 \mathrm{bp}$ 의 mRNA 염기서열을 최초로 소에서 밝혔으며 여 러 조직과 기관에서의 발현양상도 살펴보았다. 한우의 c-fos 유전자의 염기서열을 사람, 돼지 및 쥐와 비교하여 본 결과 각각 $89.8 \%, 93.5 \%$ 와 $87.0 \%$ 의 높은 상동성을 보였다. 이 유전자 의 발현은 근육중 갈비에서 가장 많은 발현량 을 보였고, 조직에서는 비장에서 가장 많은 발 현량을 보이는 것을 알 수 있었다. 이 연구에 서 밝혀진 c-fos 유전자는 SNP의 추가분석에 의해 한우에서 육질의 향상과 관련이 있는 후 보유전자로 쓰일 수 있을 것으로 사료된다.

$$
\mathrm{V} \text { 사 사 }
$$

본 연구는 농촌진흥청 바이오그린21사업의 지원에 의해 이루어진 연구결과의 일부이며 연 구비 지원에 감사드립니다.

\section{$\mathrm{VI}$ 인 용 문 헌}

1. Finkel, M. P., Biskis, B. O. and Jinkins, P. B. 196 6. Virus induction of osteosarcomas in mice. Science 11;151(711):698-701.

2. Glover, J. N. M. and Harrison, S. C. 1995. Crystal structure of the heterodimeric bZIP transcription factor c-Fos-c-Jun bound to DNA. Nature 373(6511): 257-261.

3. Grigoriadis, A. E., Wang, Z. Q. and Wagner, E. F. 1995. Fos and bone cell development: lessons from a nuclear oncogene. Trends. Genet. 11(11):436-441.

4. Johnson, R. S., Spiegelman, B. M. and Papaioannou, V. 1992. Pleiotropic effects of a null mutation in the c-fos proto-oncogene. Cell 71(4):577-586.

5. Korneva, E. A., Barabanova, S. V., Golovko, O. I., Nosov, M. A., Novikova, N. S. and Kazakova, T. B. 2000. C-fos and IL-2 gene expression in rat brain cells and splenic lymphocytes after nonantigenic and antigenic stimuli. Ann. N. Y. Acad. Sci. 917:197209.

6. Lehtinen, S. K., Rahkila, P., Helenius, M., Korhonen, P. and Salminen, A. 1996. Down-Regulation of Transcription Factors AP-1, Sp-1, and NF-B Precedes Myocyte Differentiation. Biochem. Biophsi. Res. Communi. 299(1):36-43.

7. Reiner, G., Heinricy, L., Brenig, B., Geldermann, H. and Dzapo, V. 2000. Cloning, structural organization, and chromosomal assignment of the porcine c-fos proto-oncogene, FOS. Cytogenet. Cell. Genet. 89(1-2):59-61. 
8. Reiner. G., Heinricy. L., Muller. E., Geldermann, H. and Dzapo, V. 2002. Indications of associations of the porcine FOS proto-oncogene with skeletal muscle fibre traits. Anim. Genet. 33(1):49-55.

9. Trouche, D., Masutani, H., Groisman, R. and Robin, P., Lenormand, J. L. and Annick, H. B. 1995. Myogenin binds to and represses c-fos promoter. FEBS Letters 361(2):140-144.

10. Van Straaten, F., Muller, R., Curran, T., Van Beveren, C. and Verma, I. M. 1983. Complete nucleotide sequence of a human c-onc gene: deduced amino acid sequence of the human c-fos protein. Proc. Nat. Acad. Sci. 80(11):3183-3187.

11. Wang, Z. Q., Grigoriadis, A. E., Mohle-Steinlein, U. and Wagner, E. F. 1991. A novel target cell for c-fos-induced oncogenesis:development of chon- drogenic tumours in embryonic stem cell chimeras. EMBO J. 10(9):2437-2450.

12. Wang, Z. Q., Ovitt, C., Grigoriadis, A. E., MohleSteinlein, U., Ruther, U. and Wanger, E. F. 1992. Bone and haematopoietic defects in mice lacking cfos. Nature 360(6406):741-745.

13. Zhang, H., Hu, P., Wen, X. L. and Huang, B. 1999. The effect of simulated weightlessness on the function of spleen lymphocytes and the expression of c-fos proto-oncogene in tail-suspended mice. Space. Med. Med. Eng. (Beijing). 12(6):423-425.

14. Zhang, J., Zhang, D., McQuade, J. S., Behbehani, M., Tsien, J. Z. and Xu, X. 2002. c-fos regulates neuronal excitability and survival. Nat. Genet. 30 (4):416-420.

(접수일자 : 2003. 6. 23. / 채택일자 : 2003. 10. 1.) 